\title{
Article \\ Grafting of (3-Chloropropyl)-Trimethoxy Silane on Halloysite Nanotubes Surface
}

\author{
Asmaa M. Abu El-Soad 1,2,*, Giuseppe Lazzara ${ }^{3, * \mathbb{D}}$, Alexander V. Pestov 1,4, Daria P. Tambasova ${ }^{1}$, \\ Denis O. Antonov ${ }^{1}$, Giuseppe Cavallaro ${ }^{3}$ and Elena G. Kovaleva ${ }^{1}$
}

1 Department of Technology of Organic Synthesis, Institute of Chemical Technology, Ural Federal University, Mira St. 19, 620002 Yekaterinburg, Russia; pestov@ios.uran.ru (A.V.P.); d.p.tambasova@urfu.ru (D.P.T.); d.o.antonov@urfu.ru (D.O.A.); e.g.kovaleva@urfu.ru (E.G.K.)

2 Nuclear Materials Authority, P.O. Box 530, El Maadi, Cairo 11381, Egypt

3 Dipartimento di Fisica e Chimica, Università degli Studi di Palermo, Viale delle Scienze, Parco d'Orleans II, Ed. 17, 90128 Palermo, Italy; giuseppe.cavallaro@unipa.it

4 Institute of Organic Synthesis, Ural Branch of the Russian Academy of Sciences, 620002 Yekaterinburg, Russia

* Correspondence: aabuelsoad@urfu.ru (A.M.A.E.-S.); giuseppe.lazzara@unipa.it (G.L.); Tel.: +79-827-280-946 (A.M.A.E.-S.); +39-328-427-9554 (G.L.)

Citation: Abu El-Soad, A.M.; Lazzara, G.; Pestov, A.V.; Tambasova, D.P.; Antonov, D.O.; Cavallaro, G.; Kovaleva, E.G. Grafting of (3-Chloropropyl)-Trimethoxy Silane on Halloysite Nanotubes Surface. Appl. Sci. 2021, 11, 5534. https:// doi.org/10.3390/app11125534

Academic Editor: Ioannis Kartsonakis

Received: 24 April 2021

Accepted: 10 June 2021

Published: 15 June 2021

Publisher's Note: MDPI stays neutral with regard to jurisdictional claims in published maps and institutional affiliations.

Copyright: (c) 2021 by the authors. Licensee MDPI, Basel, Switzerland. This article is an open access article distributed under the terms and conditions of the Creative Commons Attribution (CC BY) license (https:// creativecommons.org/licenses/by/ $4.0 /)$.

\begin{abstract}
Modified halloysite nanotubes (HNTs-Cl) were synthesized by a coupling reaction with (3-chloropropyl) trimethoxysilane (CPTMS). The incorporation of chloro-silane onto HNTs surface creates HNTs-Cl, which has great chemical activity and is considered a good candidate as an active site that reacts with other active molecules in order to create new materials with great applications in chemical engineering and nanotechnology. The value of this work lies in the fact that improving the degree of grafting of chloro-silane onto the HNT's surface has been accomplished by incorporation of HNTs with CPTMS under different experimental conditions. Many parameters, such as the dispersing media, the molar ratio of $\mathrm{HNTs} / \mathrm{CPTMS} / \mathrm{H}_{2} \mathrm{O}$, refluxing time, and the type of catalyst were studied. The greatest degree of grafting was accomplished by using toluene as a medium for the grafting process, with a molar ratio of $\mathrm{HNTs} / \mathrm{CPTMS} / \mathrm{H}_{2} \mathrm{O}$ of $1: 1: 3$, and a refluxing time of $4 \mathrm{~h}$. The addition of $7.169 \mathrm{mmol}$ of triethylamine $\left(\mathrm{Et}_{3} \mathrm{~N}\right)$ and $25.97 \mathrm{mmol}$ of ammonium hydroxide $\left(\mathrm{NH}_{4} \mathrm{OH}\right)$ led to an increase in the degree of grafting of CPTMS onto the HNT's surface.
\end{abstract}

Keywords: grafting; halloysite nanotubes; CPTMS

\section{Introduction}

Halloysite is a naturally occurring dioctahedral 1:1 clay mineral that belongs to the kaolinite group. The unit layer of kaolinite is composed of one $\mathrm{SiO}_{4}$ tetrahedral layer and one $\mathrm{AlO}_{2}(\mathrm{OH})_{4}$ octahedral layer. The chemical formula of the unitary cell for halloysite differs from kaolinite by its water content in the interlayer spaces [1,2]. It is composed of hollow cylinders that are formed by multiple rolled layers [3]. Halloysite has four types of surface: (i) an internal lumen surface, composed of hydrophilic aluminol (Al-OH) groups; (ii) an external surface, composed of hydrophobic siloxane ( $\mathrm{Si}-\mathrm{O}-\mathrm{Si}$ ) groups; (iii) an interlayer surface that is chemically the same as the internal lumen surface; and (iv) an edge surface, terminated by $(\mathrm{Al}-\mathrm{OH})$ and $(\mathrm{Si}-\mathrm{OH})$ groups. On the outer surface of the tube, the siloxane is located and a negative surface charge density is observed, while on the inner surface of the tube, the $(\mathrm{Al}-\mathrm{OH})$ groups are responsible for the positive surface charge density in a relatively high $\mathrm{pH}$ range. The net charge of halloysite nanotubes is negative [4]. The typical size of HNTs is: diameter less than $0.1 \mu \mathrm{m}$. while the lengths range from 0.5 to $1.2 \mu \mathrm{m}$ depending on the deposit $[5,6]$. Compared to other tube-shaped materials such as boron nitride, metal oxide, and carbon nanotubes, halloysite gains attention as an attractive and appropriate material for nanotechnology applications because of its nature and its availability [4,7-13]. Halloysite mineral surfaces can be altered using different methods, i.e., adsorption, grafting with organic compounds, and ion exchange using inorganic/ organic 
cations [14-18]. One of these methods that can be used to modify the halloysite nanotube surface is the grafting of silane, improving HNTs' clay dispersion in polymeric, fluidic materials $[18,19]$. It is worth noting that halloysite nanotubes have garnered great interest as polymeric fillers due to their reinforcing ability, but also due to the possibility of controlled release of active ingredients for packaging applications and drug delivery [20-23]. The silanization route is performed via the reaction of organosilane with the hydroxyl groups of nanotubes to create the siloxane bonds.

In our previous work, the conditions for the grafting process were studied in detail. In those papers, three types of silanes: (3-mercaptopropyl) trimethoxy silane, (3-glycidyl oxypropyl) trimethoxy silane, and (3-aminopropyl) triethoxy silane were grafted onto the HNT surface and the degree of grafting was $99.8,93.3$, and $22.4 \%$, respectively [24,25]. The literature reports on other silica $\left(\mathrm{SiO}_{2}\right)$-based mesoporous materials and their surface modification as a strategic aspect for the compatibilization with polymeric matrices [26-28].

The present work is focused on grafting of (3-chloropropyl) trimethoxy silane on the halloysite nanotube surface using different experimental conditions that aim to achieve the best degree of functionalization. This route of functionalization is of great benefit to improve HNTs' dispersion characteristics as filler, and interaction with hydrophobic polymers. Successful organomodification strongly depends on the reaction conditions, i.e., solvent polarity, number of moles of silane, amount of water that can be inserted into the reaction media, and catalyst.

\section{Materials and Methods}

\subsection{The Materials}

The halloysite nanotubes are a Sigma-Aldrich product (St. Louis, MO, USA). (3Chloropropyl) trimethoxy silane (CPTMS) is an Alfa Aesar product (Tianjin, China). Triethylamine $\left(\mathrm{Et}_{3} \mathrm{~N}\right)$, tetra-ethoxy titanium $(\mathrm{EtO})_{4} \mathrm{Ti}$, and ammonium hydroxide $\left(\mathrm{NH}_{4} \mathrm{OH}\right)$ were obtained from Alfa Aesar (China). All the solvents that were used in this work were of analytical grade and were used as received.

\subsection{Methods}

The halloysite nanotubes were treated with (3-chloropropyl) trimethoxysilane (CPTMS) in toluene, tetrahydrofuran (THF), ethanol, n-hexane, and 1,4 dioxane for $4 \mathrm{~h}$ under reflux conditions. The effect of the catalyst (triethylamine, urea, tetra-ethoxy titanium, and ammonia solution) on the proceeding of the reaction was evaluated, and moistening of the reaction media was tested as mentioned in Table 1 . The obtained material was washed several times with acetone followed by ethanol and dried in an oven at $60^{\circ} \mathrm{C}$ for $12 \mathrm{~h}$. The reaction scheme is provided in Figure 1.

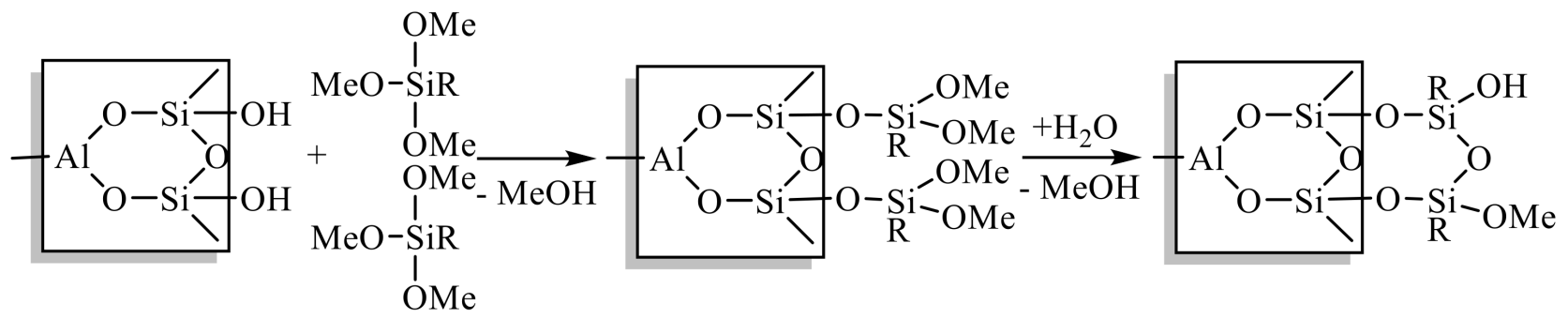

$\mathrm{R}-\left(\mathrm{CH}_{2}\right)_{3} \mathrm{Cl}$

Figure 1. The synthetic route that was used during the grafting of CPTMS onto the HNT surface. 
Table 1. The different parameters which were used for the grafting process and the results obtained from elemental analysis.

\begin{tabular}{|c|c|c|c|c|c|c|c|}
\hline \multirow{2}{*}{$\begin{array}{c}\text { Molar Ratio } \\
\left(\mathrm{HNTs} / \mathrm{CPTMS} / \mathrm{H}_{2} \mathrm{O}\right)\end{array}$} & \multirow{2}{*}{ Solvent } & \multirow{2}{*}{ Catalyst } & \multirow{2}{*}{$\mathrm{T} /{ }^{\circ} \mathrm{C}$} & \multirow{2}{*}{$\begin{array}{l}\text { Refluxing } \\
\text { Time (h) }\end{array}$} & \multicolumn{2}{|c|}{ Content, $\%$} & \multirow{2}{*}{$\begin{array}{c}\text { Degree of } \\
\text { Grafting (\%) }\end{array}$} \\
\hline & & & & & $\mathrm{C}$ & $\mathbf{H}$ & \\
\hline 1:1:0 & $20 \mathrm{~mL}$ toluene & & 110 & 4 & 2.17 & 1.83 & 24.29 \\
\hline 1:1.33:0 & $20 \mathrm{~mL}$ THF & & 66 & 4 & 1.20 & 1.63 & 11 \\
\hline $1: 1: 3$ & $20 \mathrm{~mL}$ toluene & & 110 & 4 & 3.26 & 2.22 & 36.5 \\
\hline 1:1:0 & $20 \mathrm{~mL}$ ethanol & & 79 & 4 & 0.96 & 1.53 & 10.75 \\
\hline $1: 1.33: 0$ & $5 \mathrm{~mL}$ toluene & & 110 & 4 & 1.40 & 1.90 & 12.84 \\
\hline 1:1:0 & $20 \mathrm{~mL}$ toluene & & 110 & 35 & 2.01 & 1.86 & 22.5 \\
\hline 1:1:0 & $20 \mathrm{~mL}$ toluene & & 110 & 48 & 1.89 & 1.97 & 21.16 \\
\hline $1: 2: 0$ & $20 \mathrm{~mL}$ toluene & & 110 & 4 & 2.41 & 2.03 & 17.13 \\
\hline 1:2:0 & $17 \mathrm{~mL}$ toluene & & 110 & 48 & 2.98 & 1.95 & 21.19 \\
\hline $1: 1: 3$ & $20 \mathrm{~mL}$ toluene & $0.5 \mathrm{~mL} \mathrm{Et}_{3} \mathrm{~N}$ & 110 & 7 & 4.31 & 2.85 & 48.26 \\
\hline $1: 1: 3$ & $20 \mathrm{~mL}$ toluene & $0.2 \mathrm{~g}$ urea & 110 & 4 & 6.63 & 2.97 & 27.77 \\
\hline 1:1.33:0 & 20 mL n-hexane & $1 \mathrm{~mL} \mathrm{Et}_{3} \mathrm{~N}$ & 69 & 4 & 3.69 & 2.14 & 33.83 \\
\hline $1: 1.33: 0$ & $20 \mathrm{~mL} \mathrm{1,4}$ dioxane & $1 \mathrm{~mL} \mathrm{Et}_{3} \mathrm{~N}$ & 100 & 4 & 2.655 & 2.175 & 24.34 \\
\hline $1: 1.33: 0$ & 20 mL n-hexane & & 69 & 4 & 1.67 & 1.96 & 15.320 \\
\hline $1: 1.33: 0$ & $20 \mathrm{~mL} \mathrm{1,4}$ dioxane & & 100 & 4 & 1.56 & 1.86 & 14.3 \\
\hline 1:1:3 & $20 \mathrm{~mL}$ toluene & $0.5 \mathrm{~mL} \mathrm{Et}_{3} \mathrm{~N}$ & 110 & 4 & 4.84 & 2.22 & 54.19 \\
\hline $1: 1: 3$ & $40 \mathrm{~mL}$ toluene & $0.5 \mathrm{~mL} \mathrm{Et}_{3} \mathrm{~N}$ & 110 & 4 & 4.55 & 2.13 & 50.95 \\
\hline $1: 1: 3$ & $20 \mathrm{~mL}$ toluene & $\begin{array}{c}0.5 \mathrm{~mL} \mathrm{Et}_{3} \mathrm{~N}+0.5 \\
\mathrm{~mL} \mathrm{NH}_{4} \mathrm{OH}\end{array}$ & 110 & 4 & 7.26 & 2.55 & 81.35 \\
\hline $1: 1: 0$ & $20 \mathrm{~mL}$ toluene & 3 drops $(\mathrm{EtO})_{4} \mathrm{Ti}$ & 110 & 4 & 3.17 & 2.1 & 35.49 \\
\hline $1: 1: 3$ & $20 \mathrm{~mL}$ toluene & $\begin{array}{c}0.5 \mathrm{~mL} \mathrm{Et}_{3} \mathrm{~N}+0.138 \\
\mathrm{~mL} \mathrm{NH}_{4} \mathrm{OH}\end{array}$ & 110 & 4 & 4.52 & 2.24 & 50.67 \\
\hline
\end{tabular}

\subsection{Characterization of HNTs-CPTMS}

An elemental analyzer, Perkin Elmer PE 2400 (Perkin Elmer, Waltham, MA, USA), was used to perform elemental analysis of carbon and hydrogen (EA) of the grafted HNT samples which were altered by (3-chloropropyl) trimethoxy silane. The degree of grafting (DG) of HNTs-CPTMS samples were obtained using Equation (1) [20,21]:

$$
D G=\frac{\text { carbon }(\%) \text { obtained from } E A}{\text { carbon content }(\%) \text { theoretically }}
$$

and the carbon content (\%) theoretically can be computed by using Equation (2):

carbon content $(\%)$ theoretically $=\frac{\text { No. of carbon atoms in CPTMS } * \text { No. of moles of CPTMS } * 12}{\text { No.of g of HNTs }+ \text { No. of g of CPTMS }- \text { No. of g of alcohol eliminated }}$

The confirmation of the grafting of (3-chloropropyl) trimethoxy silane onto the halloysite nanotube surface was done by characterization of the obtained material using Fourier transform infrared (FT-IR) spectra. Compact FT-IR Spectrometer: ALPHA II (Manufacturer Bruker Optics) was used for FT-IR measurements in the wavenumber range (4500-500) $\mathrm{cm}^{-1}$ by considering 24 scans, and each scan was $30 \mathrm{~s}$. Thermogravimetric analysis (TGA) was done by a Mettler Toledo device (Columbus, OH, USA) for the unmodified halloysite nanotubes and the greatest modified sample (HNTs-CPTMS). The mass of the sample was measured against time during the temperature changes from 27 to $1000{ }^{\circ} \mathrm{C}$ with a heating rate of $30^{\circ} \mathrm{C} \mathrm{min}-1$ under a nitrogen flow of $60 \mathrm{~mL} / \mathrm{min}$. Scanning electron microscope (SEM) images were obtained by using a Carl Zeiss EVO LS 10 Device (Manufacturer: Carl Zeiss NTS, Jena, Germany). It was used to study the morphology of unmodified halloysite nanotubes and the greatest modified sample (HNTs-CPTMS). Carbon tape was used to reduce charging effects. Minimal electron dose was used ( $3 \mathrm{kV})$ and the sample distance was $5.1 \mathrm{~mm}$. 


\section{Results and Discussion}

In principle, halloysite has four distinguished surfaces: (i) an internal lumen surface, composed of hydrophilic aluminol (Al-OH) groups; (ii) an external surface, composed of hydrophobic siloxane (Si-O-Si) groups; (iii) an interlayer surface that is chemically the same as the internal lumen surface; and (iv) edge surfaces, terminated by Al-OH and $\mathrm{Si}-\mathrm{OH}$ groups. These $\mathrm{Si}-\mathrm{OH}$ groups can condense with the surface hydroxyl groups of inorganic materials by eliminating water molecules under proper conditions. In the current work, the expected mechanism for the grafting is a two-step process: first, the hydrolysis of methoxy groups of CPTMS to form intermediate species; second, the creation of siloxane bonds as described in Figure 1. Similar mechanisms were reported for the reaction of silanes with silica gel [29]. In the following, the effect of reaction conditions on the modification efficacy are highlighted.

\subsection{Effect of Solvent}

Choosing the appropriate solvent is of great importance for the silanization of halloysite nanotubes using (3-chloropropyl) trimethoxy silane due to the effect of solvent on both the rate and thermodynamic route of the chemical modification process. The solvent can act as a source of protons or act as a base. Moreover, the solvation of the reactant can be also considered. In the present work, many solvents have been tested for the silanization of halloysite nanotubes using (3-chloropropyl) trimethoxy silane, such as ethanol, toluene, tetrahydrofuran, 1,4-dioxane, and n-hexane. The nature of these solvents affects the grafting degree of CPTMS onto the HNT surface as mentioned in Table 1. The degree of grafting of CPTMS onto HNTs using ethanol, toluene, tetrahydrofuran, 1,4-dioxane, and n-hexane was $10.75,24.29,11,14.3$, and $15.32 \%$, respectively. Relying on the data obtained from elemental analysis, it was found that toluene is the most effective solvent for the grafting of (3-chloropropyl) trimethoxy silane onto the HNT surface $[18,30]$.

\subsection{Effect of HNTs:CPTMS: $\mathrm{H}_{2} \mathrm{O}$ Molar Ratio}

Even though an increasing concentration of reactants results in enhancing the chance of collisions between the reactant molecules, hence speeding the rate of reaction, increasing the number of moles of CPTMS results in decreasing the degree of grafting of CPTMS onto the HNT surface. This observation has no clear explanation [31-34]. The molar ratio HNTs/CPTMS $/ \mathrm{H}_{2} \mathrm{O}$ has been varied: 1:1:0, 1:2:0, 1:1.33:0, and 1:1:3. According to the data obtained from elemental analysis, the greatest degree of grafting was achieved by using the molar ratio 1:1:3. As reported in our recent work, the effect of HNT/silane molar ratio on silanization of HNTs using (3-aminopropyl) triethoxy silane and (3-mercaptopropyl) trimethoxy silane was studied, and the results reveal that the degree of grafting of silane onto the HNT surface decreased as the number of moles of silane increased [2,18,35]. In the present work, it was found that for a HNTs:CPTMS: $\mathrm{H}_{2} \mathrm{O}$ molar ratio equal to 1:1:3, a larger degree of grafting is obtained (Table 1).

\subsection{Effect of Catalyst on Silanization of HNTs Using CPTMS}

A catalyst can alter the rate of a chemical reaction and remain chemically unchanged, because it works only to reduce the energy of the rate-limiting transition state. It has no effect on the quantity of the product formed. Urea, triethylamine, ammonium hydroxide, and tetra-ethoxy titanium have been used to increase the rate of grafting CPTMS onto the HNT surface. The addition of $0.5 \mathrm{~mL} \mathrm{Et}_{3} \mathrm{~N}+0.5 \mathrm{~mL} \mathrm{NH}_{4} \mathrm{OH}$ as catalysts enhances the condensation reaction between silane molecules and the hydroxyl groups on the surface of the halloysite mineral. This is explained by relying on the fact that both $\mathrm{NH}_{4} \mathrm{OH}$ and $\mathrm{Et}_{3} \mathrm{~N}$ act as Bronsted bases, which enhances the proton transfer mechanism. This can be clearly noticed from the enhancement of the degree of grafting, as shown in Table 1. 


\subsection{Effect of Time}

The effect of time on the degree of grafting of CPTMS onto halloysite nanotubes' surface has been discussed, and the data are reported in Table 1 . The time was changed to be equal to 4,35 , and $48 \mathrm{~h}$. The results of elemental analysis show that the degree of grafting decreased as the reaction time increased and the loss of the degree of grafting was not significant. The degree of grafting decreased according to the following order: 24.29, 22.5 , and $21.16 \%$ for 4,35 , and $48 \mathrm{~h}$, respectively.

\subsection{Effect of the Volume of Toluene}

Toluene was chosen as the best solvent according to the data of the elemental analysis. The volume of toluene changed from 20 to $40 \mathrm{~mL}$ and the degree of grafting was calculated. The results show a decrement in grafting degree from 54.19 to $50.95 \%$ for utilization of 20 and $40 \mathrm{~mL}$ of toluene, respectively.

\subsection{Characterization of the Sample Which Has the Greatest Degree of Grafting Using CPTMS}

The sample which had the highest degree of grafting using CPTMS was distinguished by using FT-IR measurements (Figure 2), TGA (Figure 3), SEM (Figure 4) analysis, and elemental analysis for $\mathrm{C}$ and $\mathrm{H}$ (Table 1). The FT-IR measurements for unmodified and modified HNTs show the two sharp bands at 3680 and $3618 \mathrm{~cm}^{-1}$ for HNT that represent the hydroxyl group, $(\mathrm{O}-\mathrm{H})$ stretching vibrations. The band at $1652 \mathrm{~cm}^{-1}$ for unmodified HNT represents the deformation of $(\mathrm{O}-\mathrm{H})$ stretching of intercalated water, as shown in Figure 2 [36]. The new band that appears at $2925 \mathrm{~cm}^{-1}$ for modified HNT represents the $\mathrm{CH}_{2}$ stretching vibration, and this confirms the creation of siloxane bonds. The presence of $\mathrm{CH}_{2}$ groups confirms the coating of HNTs by CPTMS molecules. The TGA results of unmodified HNT shows the main mass loss at $400-500{ }^{\circ} \mathrm{C}$, as is reported for the dehydration of hydroxyl groups that are located on the HNT surface [37]. The modified HNT shows an additional mass loss step between 300 and $450{ }^{\circ} \mathrm{C}$, indicating the presence of the organic moieties on the HNT surface as shown in Figure 3. Finally, the SEM morphologies confirmed that the surface modification and reaction conditions did not alter the tubular shape of the halloysite nanotubes, and the halloysite tubes are coated with CPTMS with noticeable sticking together of species (Figure 4).

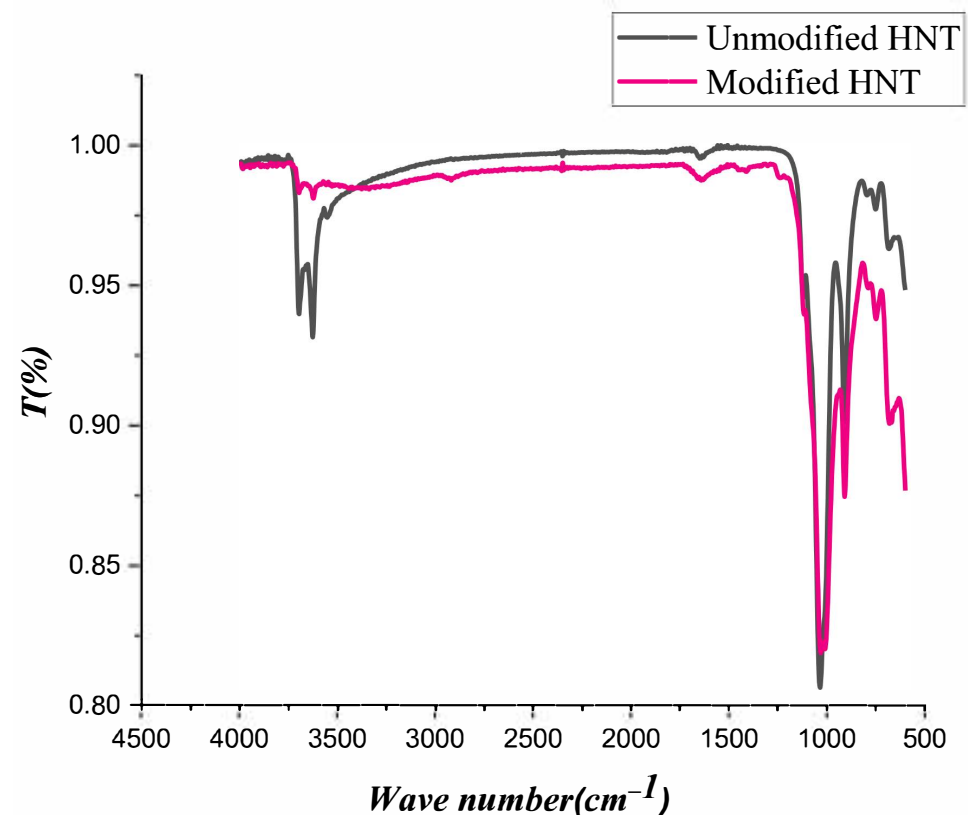

Figure 2. FT-IR spectra of unmodified HNT and modified HNT sample. 


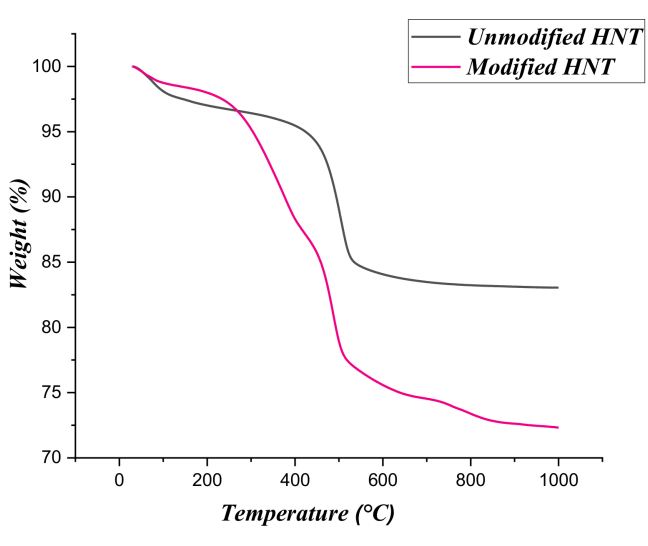

(a)

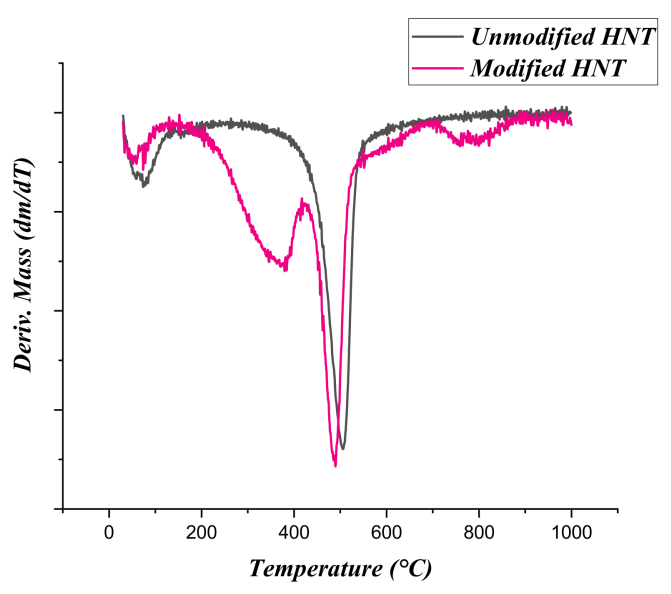

(b)

Figure 3. TGA curves of unmodified HNT and modified HNT sample (a) and DTG curves of unmodified HNT and modified HNT sample (b).

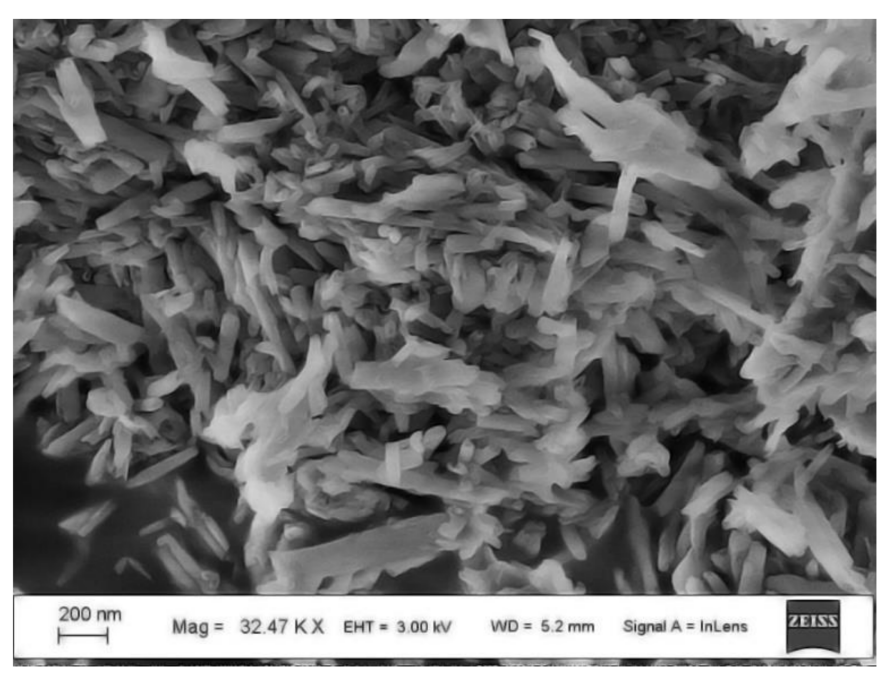

(a)

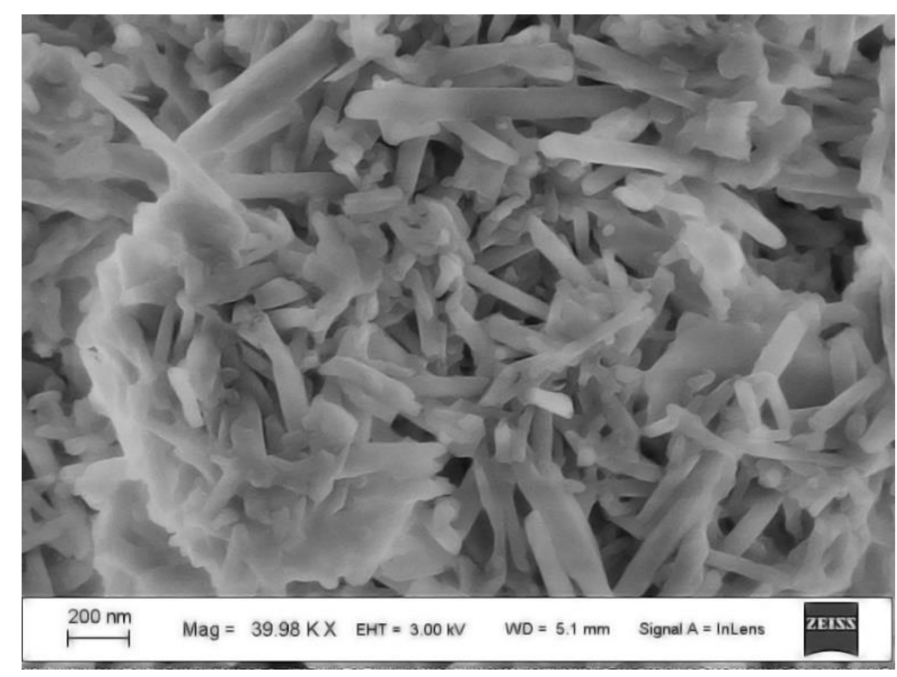

(b)

Figure 4. SEM image of unmodified HNT (a) and modified HNT sample (b).

\section{Conclusions}

(3-chloropropyl) trimethoxy silane was grafted onto the halloysite nanotube surface using a variety of solvents, and toluene was chosen as the best solvent for the silanization process. The amount of silane was varied and the best molar ratio of HNTs $/ C P T M S / \mathrm{H}_{2} \mathrm{O}$ was 1:1:3. It was found that adding small quantities of tri-ethyl amine and ammonia solution led to the enhancement of the degree of grafting of CPTMS onto the HNT surface. The samples with the best grafting yield were characterized and the obtained hybrid material showed that the halloysite tubes were coated with CPTMS, with noticeable sticking of nanotubes.

Author Contributions: Conceptualization, G.L., E.G.K., and A.M.A.E.-S.; investigation, A.V.P., D.P.T., and D.O.A.; data curation, A.M.A.E.-S. and G.C.; writing-original draft preparation, G.C. and A.M.A.E.-S.; writing—review and editing, G.L. and G.C.; funding acquisition, G.L. and E.G.K. All authors have read and agreed to the published version of the manuscript. 
Funding: This research was funded by Program 211 of the Government of the Russian Federation No. 02.A03.21.0006, RFBR grants 17-03-00641 and 18-29-12129 mk, the State Task from the Ministry of the Education and Science of the Russian Federation No. 4.9514.2017/8.9.

Institutional Review Board Statement: Not applicable.

Informed Consent Statement: Not applicable.

Conflicts of Interest: The authors declare no conflict of interest.

\section{References}

1. Joussein, E.; Petit, S.; Churchman, J.; Theng, B.; Righi, D.; Delvaux, B. Halloysite clay minerals-a review. Clay Min. 2005, 40, 383-426. [CrossRef]

2. Osipova, V.A.; Pestov, A.V.; Mekhaev, A.V.; Abu El-Soad, A.M.; Tambasova, D.P.; Antonov, D.O.; Kovaleva, E.G. Functionalization of Halloysite by 3-Aminopropyltriethoxysilane in Various Solvents. Pet. Chem. 2020, 60, 597-600. [CrossRef]

3. Szczepanik, B. Photocatalytic degradation of organic contaminants over clay-TiO2 nanocomposites: A review. Appl Clay Sci. 2017, 141, 227-239. [CrossRef]

4. Lazzara, G.; Cavallaro, G.; Panchal, A.; Fakhrullin, R.; Stavitskaya, A.; Vinokurov, V.; Lvov, Y. An assembly of organic-inorganic composites using halloysite clay nanotubes. Curr. Opin. Colloid Interface Sci. 2018, 35, 42-50. [CrossRef]

5. Cavallaro, G.; Chiappisi, L.; Pasbakhsh, P.; Gradzielski, M.; Lazzara, G. A structural comparison of halloysite nanotubes of different origin by Small-Angle Neutron Scattering (SANS, and Electric Birefringence. Appl. Clay Sci. 2018, 160, 71-80. [CrossRef]

6. Pasbakhsh, P.; Churchman, G.J.; Keeling, J.L. Characterisation of properties of various halloysites relevant to their use as nanotubes and microfibre fillers. Appl. Clay Sci. 2013, 74, 47-57. [CrossRef]

7. Sadjadi, S. Halloysite-based hybrids/composites in catalysis. Appl. Clay Sci. 2020, 189, 105537. [CrossRef]

8. Bertolino, V.; Cavallaro, G.; Milioto, S.; Lazzara, G. Polysaccharides/Halloysite nanotubes for smart bionanocomposite materials. Carbohydr. Polym. 2020, 245, 116502. [CrossRef] [PubMed]

9. Cavallaro, G.; Milioto, S.; Lazzara, G. Halloysite Nanotubes: Interfacial Properties and Applications in Cultural Heritage. Langmuir 2020, 36, 3677-3689. [CrossRef]

10. Lvov, Y.; Panchal, A.; Fu, Y.; Fakhrullin, R.; Kryuchkova, M.; Batasheva, S.; Stavitskaya, A.; Glotov, A.; Vinokurov, V. Interfacial Self-Assembly in Halloysite Nanotube Composites. Langmuir 2019, 35, 8646-8657. [CrossRef]

11. Lvov, Y.M.; DeVilliers, M.M.; Fakhrullin, R.F. The application of halloysite tubule nanoclay in drug delivery. Expert Opin. Drug Deliv. 2016, 13, 977-986. [CrossRef]

12. Cavallaro, G.; Milioto, S.; Parisi, F.; Lazzara, G. Halloysite Nanotubes Loaded with Calcium Hydroxide: Alkaline Fillers for the Deacidification of Waterlogged Archeological Woods. ACS Appl. Mater. Interfaces 2018, 10, 27355-27364. [CrossRef]

13. Lisuzzo, L.; Hueckel, T.; Cavallaro, G.; Sacanna, S.; Lazzara, G. Pickering Emulsions Based on Wax and Halloysite Nanotubes: An Ecofriendly Protocol for the Treatment of Archeological Woods. ACS Appl. Mater. Interfaces 2021, 13, 1651-1661. [CrossRef] [PubMed]

14. Guo, B.; Liu, X.; Zhou, W.Y.; Lei, Y.; Jia, D. Adsorption of ionic liquid onto halloysite nanotubes: Mechanism and reinforcement of the modified clay to rubber. J. Macromol. Sci. Part B 2010, 49, 1029-1043. [CrossRef]

15. Wang, J.; Sun, K.; Hao, W.; Du, Y.; Pan, C. Structure and properties research on montmorillonite modified by flame-retardant dendrimer. Appl. Clay Sci. 2014, 90, 109-121. [CrossRef]

16. Liu, M.; Wu, C.; Jiao, Y.; Xiong, S.; Zhou, C. Chitosan-halloysite nanotubes nanocomposite scaffolds for tissue engineering. J. Mater. Chem. B 2013, 1, 2078-2089. [CrossRef] [PubMed]

17. Cavallaro, G.; Milioto, S.; Konnova, S.; Fakhrullina, G.; Akhatova, F.; Lazzara, G.; Fakhrullin, R.; Lvov, Y. Halloysite/Keratin Nanocomposite for Human Hair Photoprotection Coating. ACS Appl. Mater. Interfaces 2020, 12, 24348-24362. [CrossRef]

18. El-Soad, A.M.A.; Abd El-Magied, M.O.; Atrees, M.S.; Kovaleva, E.G.; Lazzara, G. Synthesis and characterization of modified sulfonated chitosan for beryllium recovery. Int. J. Biol. Macromol. 2019, 139, 153-160. [CrossRef] [PubMed]

19. Haijiao, K.; Xiaorong, L.; Shifeng, Z.; Jianzhang, L. Functionalization of halloysite nanotubes (HNTs) via mussel-inspired surface modification and silane grafting for HNTs/soy protein isolate nanocomposite film preparation. RSC Adv. 2017, 7, $24140-24148$.

20. Lisuzzo, L.; Caruso, M.R.; Cavallaro, G.; Milioto, S.; Lazzara, G. Hydroxypropyl Cellulose Films Filled with Halloysite Nanotubes/Wax Hybrid Microspheres. Ind. Eng. Chem. Res. 2021, 60, 1656-1665. [CrossRef]

21. Lisuzzo, L.; Cavallaro, G.; Milioto, S.; Lazzara, G. Effects of Halloysite Content on the Thermo-Mechanical Performances of Composite Bioplastics. Appl. Clay Sci. 2020, 185, 105416. [CrossRef]

22. Govindasamy, K.; Dahlan, N.A.; Janarthanan, P.; Goh, K.L.; Chai, S.-P.; Pasbakhsh, P. Electrospun Chitosan/Polyethylene-Oxide (PEO)/Halloysites (HAL) Membranes for Bone Regeneration Applications. Appl. Clay Sci. 2020, 190, 105601. [CrossRef]

23. Gorrasi, G.; Bugatti, V.; Ussia, M.; Mendichi, R.; Zampino, D.; Puglisi, C.; Carroccio, S.C. Halloysite Nanotubes and Thymol as Photo Protectors of Biobased Polyamide 11. Polym. Degrad. Stab. 2018, 152, 43-51. [CrossRef]

24. Abu El-Soad, A.M.; Pestov, A.V.; Tambasova, D.P.; Osipova, V.A.; Martemyanov, N.A.; Cavallaro, G.; Kovaleva, E.G.; Lazzara, G. Insights into grafting of (3-Mercaptopropyl) trimethoxy silane on halloysite nanotubes surface. J. Organomet. Chem. 2020, 915, 121224. [CrossRef] 
25. Abu El-Soad, A.M.; Lazzara, G.; Pestov, A.V.; Cavallaro, G.; Martemyanov, N.A.; Kovaleva, E.G. Effect of Polarity of Solvent on Silanization of Halloysite Nanoclay Using (3-Glycidyloxy propyl, Trimethoxy Silane. J. Inorg. Organomet. Polym. Mater. 2021, 31, 2569-2578. [CrossRef]

26. Miricioiu, M.G.; Iacob, C.; Nechifor, G.; Niculescu, V.-C. High Selective Mixed Membranes Based on Mesoporous MCM-41 and MCM-41- $\mathrm{NH}_{2}$ Particles in a Polysulfone Matrix. Front. Chem. 2019, 7, 332. [CrossRef] [PubMed]

27. Niculescu, V.; Miricioiu, M.; Geana, E.-I.; Ionete, R.-E.; Paun, N.; Parvulescu, V. Silica Mesoporous Materials-An Efficient Sorbent for Wine Polyphenols Separation. Rev. Chim. 2019, 70, 1513-1517. [CrossRef]

28. Blanco, I.; Cicala, G.; Tosto, C.; Bottino, F.A. Kinetic Study of the Thermal and Thermo-Oxidative Degradations of Polystyrene Reinforced with Multiple-Cages POSS. Polymers 2020, 12, 2742. [CrossRef]

29. Gauthier, S.; Aimé, J.P.; Bouhacina, T.; Attias, A.J.; Desbat, B. Study of Grafted Silane Molecules on Silica Surface with an Atomic Force Microscope. Langmuir 1996, 12, 5126-5137. [CrossRef]

30. Pereira, C.; Patrício, S.; Silva, A.R.; Magalhães, A.L.; Carvalho, A.P.; Pires, J.; Freire, C. Copper acetylacetonate anchored onto amine-functionalised clays. J. Colloid Interface Sci. 2007, 316, 570-579. [CrossRef]

31. Xue, A.; Zhou, S.; Zhao, Y.; Lu, X.; Han, P. Effective $\mathrm{NH}_{2}$-grafting on attapulgite surfaces for adsorption of reactive dyes. J. Hazard. Mater. 2011, 194, 7-14. [CrossRef] [PubMed]

32. Javadian, H.; Koutenaei, B.B.; Shekarian, E.; Sorkhrodi, F.Z.; Khatti, R.; Toosi, M. Application of functionalized nano HMS type mesoporous silica with N-(2-aminoethyl)-3-aminopropyl methyldimethoxysilane as a suitable adsorbent for removal of Pb (II) from aqueous media and industrial wastewater. J. Saudi Chem. Soc. 2017, 21, S219-S230. [CrossRef]

33. Zhang, L.; Yu, C.; Zhao, W.; Hua, Z.; Chen, H.; Li, L.; Shi, J. Preparation of multi-amine-grafted mesoporous silicas and their application to heavy metal ions adsorption. J. Non-Cryst. Solids. 2007, 353, 4055-4061. [CrossRef]

34. Hernández-Morales, V.; Nava, R.; Acosta-Silva, Y.J.; Maclas-Sánchez, S.A.; Pérez-Bueno, J.J.; Pawelec, B. Adsorption of lead (II) on SBA-15 mesoporous molecular sieve functionalized with -NH 2 groups. Microporous Mesoporous Mater. 2012, 160, 133-142. [CrossRef]

35. Carli, L.N.; Daitx, T.S.; Soares, G.V.; Crespo, J.S.; Mauler, R.S. The effects of silane coupling agents on the properties of PHBV/halloysite nanocomposites. Appl. Clay Sci. 2014, 87, 311-319. [CrossRef]

36. Yuan, P.; Southon, P.D.; Liu, Z.; Green, M.E.R.; Hook, J.M.; Antill, S.J.; Kepert, C.J. Functionalization of Halloysite Clay Nanotubes by Grafting with $\gamma$-Aminopropyltriethoxysilane. J. Phys. Chem. C 2008, 112, 15742-15751. [CrossRef]

37. Duce, C.; Ciprioti, S.V.; Ghezzi, L.; Ierardi, V.; Tinè, M. Thermal Behavior Study of Pristine and Modified Halloysite Nanotubes. J. Therm. Anal. Calorim. 2015, 121, 1011-1019. [CrossRef] 